\title{
Model Policy Implementation Of Peace In Aceh Province, Indonesia
}

\author{
Nellis Mardhiah \\ Departement of Public Administration \\ Teuku Umar University \\ West Aceh, Indonesia \\ nellismardhiah@utu.ac.id
}

\begin{abstract}
The purpose of this study is to find out the implementation model of the policy implemented by the Aceh government in maintaining the consistency of peace as it has been entrusted in Law Number 11 Year 2006 regarding the governance of Aceh. Implementation of this action based on the decisions that have been made before is every element of the policy to be implemented from every aspect of Aceh's development of economic, political, social and cultural fields, science technology must be based on Islamic law. Similarly, the hope and purpose of the idea of Aceh's administration in establishing peace is the part of the aspect of defence and security development in Aceh based on Islamic law embodied by the Aceh government based on Helsinki MOU. The research method uses a qualitative approach based on past studies. The peace-based policy-implementation model in promoting Islamic law which is a peace-building process in Aceh has not been met in realizing the welfare of the people, justice and the protection of human rights so that the Acehnese government needs to be developed and run based on the most classic governance principles in the form of a policy model Submitted by Merilee s. Grindle (1980). The result of the research is the successful implementation of the policy is the process politic of transformation for the lives of people oriented on the factors of social and political economic conditions through the central and regional government relations followed by PERDA or qanun in the actualization of the aspect of peace building in Aceh. So the Aceh government needed institutional transformation in the best practice of government innovation to implement a peace-based policy in upholding Islamic law.
\end{abstract}

Keywords-Model Policy, Implementation, Peacefully

\section{INTRODUCTION}

$\mathrm{T}$ The development of the Aceh region has been aimed at improving regional competitiveness, improving economic growth, and promoting community upbringing. Strategic and quality regional development is the hope of every Indonesian region. So is the hope for the Aceh region. Regional development apart from improving regional competitiveness also strives to balance the development of the region according to their respective potentials. The development of key indicators in regional development includes economic growth, unemployment reduction, and poverty reduction can illustrate the achievement of regional development performance in general.

The theory of modernization and development which is basically an idea of social change in its journey has become an idiology. This development is a result of massive funding and political support from governments and organizations and private companies in the United States as well as other liberal states. All of which make modernization and development as a movement of interdisciplinary scientists of social sciences that focus on social change. As a result, modernization theory is not merely a "growing industry", but has become a school of thought, it has even become an idiology. The influence of modernization in the third world is vast, not only among academics in the Universities, but also among bureaucrats, planners and implementers of development programs in third world countries.

The Tadaro (2000) statement of modernization theory is the most dominant theory in determining the face of development. This theory is an idea that can bring the life of society to progress and slowly change from the primitive stage to the advanced stage. Based on such assumptions in the theory of modernization of development is to show six steps in the process of progressing to the following development:

1) Modernization is First, modernization is a gradual process. Rostow's theory of takeoff distinguishes the various phases of economic growth that the society is about to achieve, beginning with primitive and simple days leading to the society towards and ending the advanced and complex order;

2) Modernization as a homogenization process. It is undeniable that the process of modernization is a process that demands similarities and resemblances, and this is an indicator that the development process is said to be successful. This homogenization process occurs in several levels, the first internal homogenization, ie the homogenization that occurs within the country. That is, among the people there has been no economic and social disparity.;

3) Modernization is a process of Europeanization and Americanization or more popularly that modernization is the same as the west. It was seen that success was something of a western nature. Western countries are an unparalleled country in economic and political prosperity. And this developed country is a mentor for developing countries. In more real terms, industrialization and economic development policy is fully emulated by the developed countries without regard to the local cultural and historical factors of developing countries; 
4) Modernization is a process that does not retreat. The process of modernization is a process that can not be stopped when it is started. In other words, when it comes to contact with developed countries, the third world is unable to resist the next process;

5) Modernization takes a long time. Because modernization is an evolutionary process, so changes that can be seen also are not immediate. As such, it takes a long time to see the changes that are experienced, even taking generations to see the whole process of modernization, including the consequences of the process of modernization.

Similarly, in an An-an (2011) analytical review of the development stages undertaken by the Indonesian government is According to Rostow, the change from underdeveloped to developed can be explained in the series of stages that must be passed by all countries. Before a developing country becomes a developed country, it must pass a stage called the take off stage. This theory suggests that developing countries are just following certain rules of development for takeoff, which in turn will develop into developed countries. An important prerequisite for being able to survive, a country must be able to build agriculture, industry and commerce so as to generate sustainable economic growth.

Dependence itself means the situation in which a country's economy is conditioned by the development and expansion of the economy of another country and the economy of that country is subject to it. The Third World Country Research that applied the development model with the perspective of modernization previously had high optimism. The advancement of the United States and other Western countries with the perspective of modernization through Capitalism, was previously viewed positively as an example and source of inspiration for the economic, political and cultural progress of the world. It is now considered cynically the oppressor and the leading cause of poverty that occurred in most Third World Countries (Suwarsono, 2006).

\section{PEACE Of ACEH}

Aceh peace development that can explain the role of state and non-state actors in the existence of autonomous regions in Aceh. In this case the territory of Aceh has gained autonomous region status. The intended variables are as moderators of peace, donor country, peace process watchdog and supporters of cooperation end the fight in the peace process in Aceh. The explanation of this explanation is based on the pluralism approach in the role of the Indonesia government in establishing the peace of Aceh conflict. The approach is through 4 steps as follows:

\section{A. Intermediary of peace}

The effort to achieve peace reconciliation between Indonesian anti-government groups in Aceh with the Indonesian government began from the old order, namely during the Sukarno government in 1955. It continued during the new era of Suharto government, which was until 1998. But it did not succeed. However, the initiatives undertaken to achieve international peace by involving national and nonstate cooperation have shown results. However, political stability in Aceh has not yet reached its desired level. As a sequence of the situation, Gus Dur's government is pursuing a peace deal through international negotiations involving the United States and Henry Dunant Center (HDC) - a private diplomacy organization. But the venture has not been able to find a solution point.

However, in the era of the administration of Susilo Bambang Yudhoyono, which began in 2004 (after the defeat of Megawati Sukarnoputri 2001-2004), he has moved Finland (as a state actor) together with the Crisis Management Initiative (CMI) (as a non-state actor from Finland) To achieve the peace of Aceh conflict.

CMI is involved directly in the peace process in Aceh. It started in 2004. The CMI is a Finnish non-governmental organization under the leadership of Martti Ahtisaari. It works to resolve the conflict and build lasting peace. CMI was founded by President Martti Ahtisaari in 2000. Cantered in Helsinki and with widespread operations around the world, the CMI has a team of almost 80 dedicated professionals, bringing their experience and expertise in conflict prevention, conflict resolution and security mediation to many in this world The areas most affected by the conflict. It has been requested by the Indonesian Government and GAM to facilitate discussions between the two. The first round of eye-to-eye discussion among the parties involved in Aceh's peace began in May 2003 - to January 2005 in Helsinki. The fifth and final rounds of negotiations were held in July and the agreement was signed on 15 August 2005. CMI and President Ahtisaari continued to follow the peace process in Aceh until June 2012 (Crisis Management Initiative 2014).

\section{B. Country Donor (Donor Country) and Non-Country}

Contributing Countries means countries providing financial assistance or technical expertise to countries that need them. In the case of Aceh, as far as this survey is done, no non-state contributors are found. The role of contributors is one of the development efforts to support the existence of conflict peace in Aceh. Among the countries involved as contributors in Aceh are the United States, Japan, Australia, and the European Union. Their assistance focuses on commitment and support in the form of financial assistance in the construction and rehabilitation of Aceh after a tsunami disaster. The aid was channelled through the Aceh Rehabilitation and Reconstruction Agency (BRR) (A Joint Report of The BRR and International Partners 2005). BRR consists of three bodies: an implementing agency, led by Kuntoro Mangkusubroto; High-level Advisory Board to guide reconstruction strategies; And the Monitoring Board to monitor activities, conduct public complaints, and audit behaviour. These three bodies provide direct reports to the President of Indonesian.

\section{Procurement of the Peace Process}

Monitoring in Aceh's peace process with the central government in Indonesia is through the Aceh Monitoring Mission (AMM). The AMM consists of the European Union, five countries from ASEAN (Thailand, Malaysia, Brunei, Philippines and Singapore), Norway and Switzerland. The AMM, led by Pieter Feith of the European Union, has been 
established to monitor the implementation of various aspects of the peace agreement set out in the Memorandum of Understanding (MoU) signed by the Indonesian Government and the Free Aceh Movement (GAM) on 15 August 2005 in Helsinki, Finland. AMM was officially launched on 15 September 2005, covering a 6 month initial period. Subsequently, it was extended to 15 December 2006. The presence of AMM was based on official invitation from the Government of Indonesia and received full support from GAM leadership.

AMM has undertaken this mission tocontribute to a peaceful, comprehensive and sustainable solution to the conflict in Aceh. The European Union and ASEAN fully respect the integrity of Indonesia's territory and see the future of Aceh as being within the Unitary Republic of Indonesia. AMM is impartial and does not represent or favour any party involved.

The objective of the AMM is to assist the Indonesian Government and GAM in implementing the MoU. AMM does not take the role of negotiations. AMM also monitors the human rights situation, the process of legal change and the reintegration of GAM members. The Law on Aceh Governance was drafted by the State Parliament (DPR) on 11 July 2006 and signed by the President of Indonesia on 1 August 2006.

\section{Co-operative advocacy is contrary to dispute}

The advocacy of cooperating in fighting the conflict in Aceh is GAM and the central government of Indonesia. Both collaborate in the role played by Finland, CMI and AMM. As a result, both parties have ratified the Aceh Government Regulation No. 11 of 2006 on the Governance of Aceh.

\section{ISLAMIC LAW}

Regional development based on Islamic law follows on the Identification of the policy problem that finds that the existing legal aspect, and the action that defines the process of identification of policy problems, shows part of the political action of decision-makers. Indicates the existing law encompasses, (i) Regional Regulation of the Special Region of Aceh Number 5 Year 2000 on the Implementation of the Islamic Shari'a Regions of the Special Region of Aceh; (Ii) Qanun of Nanggroe Aceh Darussalam Province Number 11 Year 2002 About the Implementation of Islamic Sharia Field of Faith, Ibadah and Syiar Islam about Drink Room and the like; (Iii) Qanun of Nanggroe Aceh Darussalam Province Number 12 Year 2003; (Iv) Qanun of Nanggroe Aceh Darussalam Province Number 13 Year 2003 concerning Maisir and Gambling and (v) Nanggroe Aceh Darussalam Province Qanun Number 14 Year 2003 regarding Khalwat.

The development of Islamic law can be seen from the study (Siregar 2008) explains that the process of making Islamic Shari'a policy is the current challenge to be taken into account in the process of policy making in Aceh in the context of the development of Islamic law. The findings show that the policy restructuring process in the reform era in 1998 between the Indonesian government and the Aceh region to date has to be based on previous legislation in the construction of Islamic law by the Aceh government (Siregar 2008).
According to Australian researchers Hooker (2008) stated that in the process of applying the Islamic Shari'a policy in Aceh there were many challenges in which the law of the law to be applied must be "consistent and consistent" with the national legal system. In fact, in fact, the mention of the word "Islamis Law" can not be given by definition. His coronary result can not be clearly defined in the meaning of Islamic law. Similarly, in Arskal's statement (2004; 2008) explains that the fabrication of Islamic Law police in Aceh is a result of a prolonged vertical conflict between the federal government and the Aceh region. The results of his study show that Islamic law is an alternative policy option given to the Aceh region by the central government of Indonesia assessed incompatibility, contrary to national legislation, meaning ambiguity and impermanence in the formulation of Qanun of Islamic law on the powers that are owned to the regional level in upholding Islamic law .

Similarly, in the Syafingi study (2012) shows that the Indonesian constitution, the 1945 Constitution, also recognizes the granting of regional autonomy from central government to regional government in the enhancement of the Islamic law. The findings suggest that the position as an autonomous region can provide more space at the district level to plan, make rules and implement various administrative frameworks within the national framework In this context they explained that policy formulation was initiated from the basis of the central government of Indonesia to the territory of Aceh based on the law is through Law Number 44 Year 1999, Law Number 18 Year 2001, and Law 2006 Indonesian Law It also recognizes the autonomy in aspects of the enforcement of Islamic law. Their findings show that from these three laws have been passed a number of qanun in the field of Islamic law in accelerating the implementation in the territory of Aceh.

Latief (2009) study of the implementation of Islamic law in Aceh as a political transformation and Islamic law in the form of legislation in both Qanun and Regent Regulation is a political product that has been produced. His findings explain that the implementation process is challenging, and difficult to accept by the community. Sahid (2012) argues that the concept of implementing Islamic law in Aceh is more symbolically symbolized than apparently. Although there are legislative provisions on the application of Islamic law, the value of Islamic law in its application is very weak. This has led to the ultimate goal of the implementation of the Islamic Sharia law that can not be fully implemented.

Aziz study (2012) emphasizes the application of Islamic law that can be influenced by domestic politics, including liberalization elements. According to him, this is the basis of politics today in the Indonesian government. The findings show that Islamic law is a political element in the position of the united state of the Republic of Indonesia as a result of conflict negotiations in Aceh. Fahmi's (2012) study reveals about the decision-making in the PERDA and argues that the scenario of PERDA's implementation and Regulation Regulations. The findings of his second law regulation are hardly acceptable to the public because of the political interests of decision-makers in both institutions. 
Similarly, Cockrel's study (1997) explains the role of the government in the policy-making which is the next guide for this paper. Hence, all of the findings of the study have shown significant results with the study of the development of the Islamic Shariah policy. Therefore, this study can provide a new perspective, where there is a difference before that focuses on the development of peace in Aceh based on Islamic law.

\section{RESEARCh Methodology}

The method used is qualitative and data sources are primary data based on documents, secondary data based on past studies and literature review. Documents are obtained from authoritative websites and publications. Methods This study was conducted using qualitative approach by emphasizing the triangulation of data is a way to find out where researchers gather and interpret information from a single source can be verified by reference to the same thing from other sources. In addition, the sources of information that can be obtained correlate that explains the process, the phenomenon by using methods of in-depth interviews that are not structured, open and made face to face with the whistleblower (Lichtman, 2013: 7).

\section{RESULTS AND DISCUSSION}

\section{A. The Model of Aceh Development}

Policy development program is a systematic process in the Rowtow Theory's perspective. The assessment of the development process that has been implemented by the Aceh government under the UUPA is a peace-based development in implementing Islamic law is a systematic and continuing process as well as the Helsinki MoU's trust. But in the implementation of Aceh's development as in Rostow's theory of argument, the position of the Aceh region from historical fact shows the values and morality of Aceh's people implementing Islamic law.

The development of development as explained in the UUPA is five 5 arguments in the above explanation showing the condition of the Acehnese people included in the precondition to take off during Aceh's conflict and tsunami in 2004. Aceh's development has been implemented continuously in all aspects of economic well-being, defence and security politics, social and cultural and science and technology have been projected in terms of controllable development with assistance and cooperation with the international community during the post-tsunami rehabilitation and reconstruction phase in Aceh. But in this aspect of development, the concern of the Aceh government in the realization of the value of the political system in accordance with UUPA's power has not been achieved continuously. For that reason, the Acehnese government currently has the obligation of the people of Aceh to prepare the mental and morality of the skilled human resource capability in the highly customizable era of mass consumption in the era of globalization.

\section{B. Aceh Development as a Transformation}

Process Transformation of Aceh's development is a value of political action that has been established by the central government to the Aceh government in the UUPA. But in terms of the process of this transformation as a hegemonic value in the aspect of modernization development is the influence of leadership in Aceh, domination, power from parts of Indonesia nationally and internationally has the power as in MOU. The application of modernization in Indonesia seems less compatible, as well as the foundation of thinking and the use of theory in the concept of community development with modernization seems less fundamental. The harmonious development conditions in implementing the political and socio-cultural development of the Acehnese people are less relevant in the development of Aceh's development. Homogeneity through the development of the economic sector was impressed by the heterogeneous conditions, which then led to the inequality of development between regions and between development sectors. Modernization is seen as a mere economic growth, which ignores the essentials of life, namely building a constructive culture in fulfilling the will of the life movement.

\section{Progressive Change of Development}

The development of community life on a planned basis in the social and cultural aspects with the dependence of production output is mentioned as a progressive value of progress in development. David McClelland's theory of the need for achievement ( $\mathrm{n}-\mathrm{Ach}$ ), the level of community development can actually be measured by support for achievement in the community itself. The form can be from the comparison between the level of production and consumption levels, the non-'build' society is a form of life whose consumption level is greater than the level of production. Koentjaraningrat (1979) once provided a solution to the polemic 'mental attitude of Indonesians generally not yet ready for development' at a seminar event (1970), this opinion shows that Koentjaraningrat (1979) approaches through Modernization theory to analyze the development process. In another dimension, Koentjaraningrat (1979) provides an explanation that development requires an approach with a value system that lives in a society that does not fit the modern development or character of the modernization concept.

\section{CONCLUSION}

The policy of implementation model implemented in Aceh is the result of the process of political transformation for the Acehnese people in the dimension of the implementation of peace-building based on Islamic law. Therefore, it can be suggested that the process of policy implementation based on UUPA No. 11 of 2016 on the Government of Aceh can show that the economic, social and political development and security and security development phase is a systematic value process from the tsunami to the development phase of Aceh's people towards mass consumption the highest. As well as the implementation of development in Aceh as a progressive value of existence from the social and cultural values of 
Acehnese people in every aspect of their life must be based on Islamic law.

\section{Acknowledgment}

For the implementation of this study, researchers would like to thank all those who have contributed to the success of this research: Research is a scientific activity that is almost certainly done in groups or through cooperation. In the world of science and technology has advanced as now, no single model of field research conducted only by the research team. This research was conducted in Aceh Provinces of the Indonesia. Thanks to the recommended to Teuku Umar University and Faculty of Social and Political Sciences which has given the operational budget of 2017 as in the process of competitive submissions paper output research presentation in the icoposdev. Everything is a form of cooperation that explicitly shows that in the world of research we cannot act as a lone warrior.

\section{References}

[1] Grindle, Merilee S. 1980. Politics and Policy Implementation in The Third World, Princnton University Press, New Jersey.

[2] Sabatier, Paul. 1986. "Top down and Bottom up Approaches to Implementation Research" Journal of Public Policy 6, (Jan), h. 21 -48

[3] Merilee S. Grindle. 1980. Politics and Policy Implementation in the Third World,Princeton University Press, New Jersey, p. 11

[4] Budiman, A., \& Ketiga, T. P. D. (1995). Jakarta: PT Gramedia Pustaka.

[5] Todaro, Michael P., 2000. This Translation Of Economic Development, Seventh, Edition is published By Arrangement With Pearson Education Limited. (Alih Bahasa, Munandar, Haris: Pembangunan Ekonomi Di Dunia Ketiga, Jakarta Erlangga, Jilid I, hlm. 93-100.

[6] An-naf. J, 2011, Tinjauan Analitis Terhadap Model Pembangunan Indonesia, Jurnal Kybornan, Vol.2 No. 1, P. 70-82

[7] Suwarsono., dan Alvin. 2006. Perubahan Sosial Dan Pembangunan.Jakarta: Pustaka. LP3ES Indonesia.

[8] Hopmann, P. T. (2011). Conclusion: Advancing the Cause of Peace in Mindanao. Dalam P. T. Hopmann, \& I. W. Zartman, Mindanao: Understanding Conflict Washington: Johns Hopkins University. P. 261

[9] Ghosh. P. (2009), International Relations, Eastions Economy Edition, P. 31

[10] Aceh Monitoring

Mission.

(2014) http://www.acehmm.org/english/amm_menu/about.htm.
[11] Conciliation Resources. (2014). The International Contact Group in Mindanao http://www.c-r.org/sites/cr.org/files/PracticePaper_MindanaoICG_ConciliationResources_0.pdf

[12] Crisis Management Initiative. (2014). Martti Ahtisaari Centre http://www.cmi.fi/en/

[13] Dokumen Himpunan Peraturan Perundang-Undangan Tentang Pemerintahan Aceh (2006).

[14] Hooker, M. B. (2008). Indonesian Syariah: Defining a National School of Islamic Law (p. 246). Singapore: ISEAS.

[15] Siregar, H. . (2008). Lesson Learned From the Implementation of Islamic Syariah Criminal Law In Aceh. Juornal Of Law and Review, 24(2), 143-176.

[16] Arskal, S. (2004). Sharia from Below in Aceh (1930s-1960s): Islamic Identity and the Right to Self-Determination with Comparative Reference to the Moro Islamic Liberation Front (MILF). Indonesia and the Malay World, 32(92), 80-99.

[17] Arskal, S. (2008). Challenging the Secular State: The Islamization of Laws in Modern Indonesia (p. 4). Honolulu: Hawaii University Press.

[18] Syafingi, H. M. (2012). Nilai-nilai Hukum Islam dalam Peraturan Daerah Syariat Islam di Indonesia. Reasearch Law Juornal, 7(2), 136146.

[19] Latief, H. M. A. (2013). Disonansi Qanun Syariat Islam dalam Bingkai Konstitusi Hukum Indonesia: Aceh sebagai Studi Kasus. In Annual International Conference on Islaimc Studiea (p. 2279). Surabaya.

[20] Muhibbuthtabary. (2012). Membumi Perdamaian Dalam Bingkai Syariat Isla Di Aceh. Media Syariah, 2(1), 12.

[21] Isa, A. G. (2012). Paradigma Syariat Islam Dalam Kerangka Autonomi Khusus (Studi Kajian Di Provinsi Aceh). Media Syariah, XI(1), 253

[22] Latief, H. M. A. (2009). Sengkarut Syariat Atas-Bawah: Gelombang Baru, Edisi IV (p. 113). Banda Aceh: Komunitas Tikar Pandan.

[23] Sahid. H.M. (2012). Formulasi Syariat Islam dalam Pandangan Ulama dan Struktural (p. 395). Surabaya: IAIN.

[24] Aziz, A. (2012). Syriat Islam: Polemik Panjang Hubungan Islam dan Negara di Indonesia. Hukum Kajian Islam, IV(2), 203.

[25] Fahmi, C. (2012). Transformasi Falsafah dalam Penerapan Syariat Islam di Aceh. In Jurnal KAjian Hukum Islam (Vol. 6, p. 167). Banda Aceh: IAIN ARRANIRY.

[26] Cockrel, J. (1997). Public Policy Making America Cooperative Axtention Service. IP 19. University of Kentucky College of Agriculture, Lexington, and Kentucky State Universit, University of Kentucky Cooperative Extension Service.

[27] Lichtman, M. (2013). Qualitative Research in Education A. User's Guide (p. 7). United Kingdom: Sage Publication Ltd.

[28] Koentjaraningrat, (1970). Manusia dan Kebudayaan di Indonesia, Jakarta : Pt Rineka Cipta

[29] Koentjaraningrat (2002). Kebudayaan Mentalitas dan Pembangunan. Jakarta : Gramedia 